\title{
ACTIVE TRANSPORT AMONG CZECH SCHOOL-AGED CHILDREN
}

\author{
Jan Pavelka, Dagmar Sigmundová, Zdeněk Hamř́k, Michal Kalman
}

\author{
Faculty of Physical Culture, Palacký University, Olomouc, Czech Republic
}

Submitted in November, 2012

BACKGROUND: Active transport is a very important factor for increasing the level of physical activity in children, which is significant for both their health and positive physical behaviour in adult age.

OBJECTIVE: The aim of the study was to establish the proportion of Czech children aged 11 to 15 who select active transport to and from school and, at the same time, describe socio-economic and socio-demographic factors influencing active transport to and from school among children.

METHODS: To establish the socio-demographic factors affecting active transport, data of a national representative sample of 11 to 15 year-old elementary school children in the Czech Republic $(n=4,425)$. Research data collection was performed within an international research study called Health Behaviour in School Aged Children in June 2010. Statistical processing of the results was made using a logistic regression analysis in the statistical programme IBM SPSS v 20.

RESULTS: Active transport to and from school is opted for in the Czech Republic by approximately $2 / 3$ of children aged 11 to 15 . Differences between genders are not statistically significant; most children opting for active transport are aged $11(69 \%)$. An important factor increasing the probability of active transport as much as 16 times is whether a child's place of residence is in the same municipality as the school. Other factors influencing this choice include BMI, time spent using a computer or a privateroom in a family. A significant factor determining active transport by children is safety; safe road crossing, opportunity to leave a bicycle safely at school, no fear of being assaulted on the way or provision of school lockers where children can leave their items.

CONCLUSIONS: Active transport plays an important role in increasing the overall level of physical activity in children. Promotion of active transport should focus on children who spend more time using a computer; attention should also be drawn to safety associated with active transport to and from school.

Keywords: Active transport, walking, cycling, school, children, HBSC.

\section{INTRODUCTION}

Active transport is most often defined as walking, cycling, or other human-powered modes of transport (inline skating, skateboarding) used for practical purposes of getting from one place to another in everyday life (Sallis, Frank, Saelens, \& Kraft, 2004). Active transport is also perceived as an easy and effective tool to increase the level of daily physical activity (Owen, Humpel, Leslie, Bauman, \& Sallis, 2004). Walking or cycling to school is also called "active commuting" (Kerr et al., 2006; Panter, Jones, van Sluijs, \& Griffin, 2010). Active commuting is normally a repetitive behaviour along a specific route. This makes the active commuters very familiar with their individual route environments. Their perceptions of the route environments can therefore be considered to be relevant, and possibly further our understanding of the influence route environments may have on active transport in general (Wahlgren, Stigell, $\&$ Schantz, 2010). Promoting active transport is, due to the global decline in physical activity and an increase in sedentary behaviour, in the last decade becoming a major topic, which is an integral part of international initiatives aimed at increasing the level of physical activity within the population ( $\mathrm{Ng} \&$ Popkin, 2012).

The issue of dependence on motorized transport, which leads to decreased levels of physical activity and environmental degradation, has a significant negative impact on public health (Aitken, Cranny, Ferguson, Graham, \& Middleton, 2009; Mackett \& Brown, 2011). Decreasing motorized transport and more frequent use of active transport plays a significant role in increasing the level of physical activity within the population and improving the environment (Wen, Orr, Bindon, \& Rissel, 2005). Promoting physical activity among the population of cities and municipalities through the functional use of active transport thus appears to be an effective and attractive alternative in terms of local policy (Johansson, Laflamme, \& Hasselberg, 2011).

The same applies to the cost effectiveness of the respective interventions. Promoting healthy lifestyle by increasing the level of physical activity through walking and cycling is more cost effective than structured intervention schemes (Sevick et al., 2000) and appears 
ideal for accumulating the recommended three $10 \mathrm{~min}$ ute intervals of moderate to vigorous physical activity on most days of the week. Healy, Dunstan, et al. (2008) and Healy, Wijndaele, et al. (2008) state that walking and cycling can also contribute to accumulating sufficient levels of low-intensity physical activity and reducing time spent in a sedentary way, which has recently been positively correlated with increased metabolic risk factors such as overweight or increased triglycerides (Stamatakis, Hamer, \& Dunstan, 2011).

For children and young people, the journey to school represents an opportunity to engage in active transport and to increase the overall level of daily physical activity. It has also been demonstrated that school-aged children who commute to school on foot or by bike have a higher general level of physical activity (Davison, Werder, \& Lawson, 2008; Sirard \& Slater, 2008) and better cardiovascular fitness in the case of increased cycling (Cooper et al., 2006; Chillón et al., 2010). Walking and cycling also helps children develop motor skills, increases awareness of the environment and decreases high-intensity transport around schools (Davis \& Jones, 1996).

If we take into account different countries, the prevalence of active transport in different countries and environments vary considerably. Studies conducted in European countries (e.g. Sweden, Estonia, Switzerland, the United Kingdom, Denmark, the Netherlands and Spain) report a relatively high prevalence of active transport ranging from $50 \%$ to $85 \%$ (Bere, van der Horst, Oenema, Prins, \& Brug, 2008; Bringolf-Isler et al., 2008; Cooper et al., 2006; DiGuiseppi, Roberts, Li, \& Allen, 1998; Farr, Blew, Lee, Lohman, \& Going, 2011; Hillman, Adams, \& Whitelegg, 1990; Chillón et al., 2010).

In contrast, a survey carried out in the USA both nationally and in individual states as well as some smaller surveys report prevalence rates of active transport ranging from less than $5 \%$ to $50 \%$, with higher values observed more frequently in western states compared with southern states (Babey, Hastert, Huang, \& Brown, 2009; Evenson, Huston, McMillen, Bors, \& Ward, 2003; Martin, Lee, \& Lowry, 2007).

Some other higher-income countries, such as Canada and Australia, also show differences in the prevalence of active transport within the country from $30 \%$ to $60 \%$, and from $15 \%$ to $60 \%$ respectively (Booth et al., 2007; Buliung, Mitra, \& Faulkner, 2009; Robertson-Wilson, Leatherdale, \& Wong, 2008; Spallek, Turner, Spinks, Bain, \& McClure, 2006).

According to latest research, however, the proportion of school-aged children who commute to school on foot or by bike has been steadily decreasing (Black, Collins, \& Snell, 2001; McDonald, 2007; Sirard \& Slater, 2008).
The aim of the study was to establish the proportion of Czech children aged 11 to 15 who select active transport to and from school. The specific aim is to describe the chance of using active transport to and from school among children.

\section{METHODS}

\section{HBSC Study}

Health Behaviour in School Aged Children (HBSC) is a collaborative cross-national research study monitoring various health and lifestyle determinants in schoolaged children $(n=230,000)$. The aim of the study is to obtain a representative and internationally comparable set of data for the development of cross-national programmes and health promotion strategies to shape health behaviours of young people in social contexts. The study has been carried out repeatedly every four years since 1984. In 2010, the study was joined by 43 countries including USA and Canada. The Czech Republic has been involved since 1994.

\section{Participants and data collection}

The data set consisted of a selection of 86 elementary schools, where research took place in grades 5, 7 and 9 , and eight multi-year grammar schools, grades 2 and 4 (corresponds with grades 7 and 9 of elementary schools). Data collection was performed in June 2010. In classes where the survey was conducted, a total of 6,553 students were enrolled, of whom 5,709 students $(87 \%)$ were present, while the remaining 844 students (13\%) were excused. None of the students addressed refused participation in the research. Immediately upon the questionnaire application in the classes, 23 were rejected due to lack of credibility or incompleteness; 5,686 questionnaires were transferred into an electronic form. Final data inspection was performed by the International Databank, University of Bergen, Norway in compliance with the international HBSC standards. The representative data set in the Czech Republic consisted of 4,425 respondents.

\section{HBSC questionnaire}

The health behaviour in school-aged children (HBSC) student questionnaire (Currie et al., 2010) is based on the international (English) version of the questionnaire made by the WHO Coordinating Centre. Filling out of the questionnaire is anonymous and declares freedom to express a child's own opinion. The internationally approved design of the questionnaire application includes a detailed description of data processing and analysis. 


\section{HBSC questionnaire - monitored parameters of active transport}

Mode of transport to and from school - respondents were asked to indicate in the questionnaires their usual mode of transport to and from school during the current week. The question was: "What is your main mode of transport to school and from school on your typical day?" Five response options were available for either direction - walking, cycling, bus/train/tram/underground (here called "public transport", including school bus), car/motorcycle/moped and other. Respondents could elect only one type of transport for each direction.

Active commuting is operationalized as reporting either walking or cycling to school, from school or both.

The next question was directed at finding reasons for the improvement or the decision to use active transport when travelling to and from school - respondents were asked: "What would improve your journey to and from school on foot or by bike or what would make you walk or cycle to school? Please indicate how important the following things are to you." Responses are given for the following statements -1 . less heavy traffic, 2 . safe places to cross the road, 3. no fear of being assaulted on the way, 4. live closer to school, 5. company of others, 6 . school lockers to leave items, 7. leave bicycle safely at school, 8. better street lighting, 9. uninterrupted pedestrian or cycle path. Possible responses were - very important, important, unimportant, not sure.

\section{Statistical processing and interpretation of results}

For statistical processing of the results and establishing the odds ratio of using active transport to and from school logistic regression analysis was used - the Backward Stepwise Likelihood Ratio method in a statistical programme IBM SPSS v. 20. The dependent variable was Active transport to and from school, i. e. journey to and from school on foot or by bicycle ( $1=$ yes, $0=$ active transport not used). Independent variables were selected as follows - weight levels determined by BMI according to a WHO percentile graph (usual weight, overweight, obesity), gender (girl, boy), age category (11 years, 13 years, 15 years), school located in the place of residence (yes, no), watching TV less than two hours a day (yes, no), time spent using a computer for less than two hours a day (yes, no), their own room (yes, no), car in the family (yes, no). Another logistic regression (method ENTER) for determine the odd ratio of meeting health recommendation according to BMI was used. Statistical significance was set to 0.05 .

At the national level (HBSC study), the prevalence of different modes of transport (active transport, public transport or car/moped to school and from school or both directions) was compared across the different age groups of school-aged children.

\section{RESULTS}

For the purposes of this article data from 4,425 respondents was analysed, out of which 2,145 (48\%) were boys and 2,280 (52\%) girls. Age categories of children were $11(32 \%), 13(33 \%)$ and $15(35 \%)$. Overweight and obesity occurrence in boys and girls in the different categories is shown in TABLE 1. Active transport to and from school is opted for by $69 \%$ of 11 year old boys and girls, at the age of 13 it is $61 \%$ of boys and $60 \%$ of girls, at 15 active transport to school or from school was found in $66 \%$ of boys and $63 \%$ of girls.

\section{TABLE 1}

Category BMI (according to a WHO percentile graph) distributed by age and gender

\begin{tabular}{llccc}
\hline & BMI & 11 year olds & 13 year olds & 15 year olds \\
\hline Boys & Normal & $81 \%$ & $81 \%$ & $81 \%$ \\
& Overweight & $16 \%$ & $17 \%$ & $17 \%$ \\
& Obesity & $3 \%$ & $2 \%$ & $2 \%$ \\
\hline \multirow{2}{*}{ Girls } & Normal & $88 \%$ & $93 \%$ & $91 \%$ \\
& Overweight & $10 \%$ & $6 \%$ & $8 \%$ \\
& Obesity & $2 \%$ & $1 \%$ & $1 \%$ \\
\hline
\end{tabular}

The results of logistic regression (TABLE 2) indicate that children who are overweight have significantly 1.39 times higher chance of using active transport to school compared with children with normal weight. The chance of using active transport changes with age; the smallest chance was recorded for 13 year old children, between 11 and 15 year old children no significant difference in the probability of using active transport to and from school was found.

Significant variables influencing active transport to and from school include the location of the school; whether it is in the same municipality as a child's place of residence. These children have a 16 times higher chance of using active transport compared with children living in a different municipality. A certain role is played by social factors. One of the factors influencing the level of active transport is sedentary behaviour. The results indicate that children who spend more than two hours a day using a computer resp. have their own room have significantly about $17 \%$ resp. $29 \%$ a lower chance of using active transport to and from school. Although the results of logistic regression indicate that children with overweight or obesity have a higher probability of using active transport, a detailed analysis of physical activity performed with respect to weight levels showed that children with overweight have a lower chance by some $25 \%$ (TABLE 3 ) of meeting health recommendations for physical activity (World Health Organization, 2002) - physical activity of at least 60 minutes a day in five or more days a week ( $1=$ meet, $0=$ don't meet $)$ 
TABLE 2

Chance of using active transport to and from school - socio-demographic factors

\begin{tabular}{|c|c|c|c|c|}
\hline Variable & $\mathbf{n}$ & $\%^{\mathrm{a}}$ & OR & $\mathbf{C I}$ \\
\hline \multicolumn{5}{|l|}{ BMI } \\
\hline Normal & 3815 & 63.7 & Ref & \\
\hline Overweight & 534 & 69.0 & $1.393^{*}$ & $1.096-1.771$ \\
\hline Obesity & 76 & 71.1 & 1.573 & $0.842-2.929$ \\
\hline \multicolumn{5}{|l|}{ Age category } \\
\hline 11 year olds & 1426 & 68.8 & Ref & \\
\hline 13 year olds & 1456 & 60.0 & $0.719 * *$ & $0.592-0.861$ \\
\hline 15 year olds & 1522 & 64.5 & 0.918 & $0.761-1.108$ \\
\hline \multicolumn{5}{|c|}{ School in the same municipality } \\
\hline No & 1232 & 20.9 & Ref & \\
\hline Yes & 3182 & 81.3 & $16.103 * *$ & $13.645-19.003$ \\
\hline \multicolumn{5}{|c|}{ Time spent using $\mathrm{PC}<2$ hours } \\
\hline No & 1799 & 67.4 & Ref & \\
\hline Yes & 2622 & 62.4 & $0.829 * *$ & $0.710-0.967$ \\
\hline \multicolumn{5}{|c|}{ Has their own room } \\
\hline No & 1927 & 70.8 & Ref & \\
\hline Yes & 2498 & 59.6 & $0.713^{* *}$ & $0.611-0.832$ \\
\hline
\end{tabular}

Legend: $\%$ a - proportion of respondents who indicated using active transport to school or from school OR - odds ratio, (CI 95\%) - confidence interval, ${ }^{*} p<0.05,{ }^{*} p<0.01$, Nagelkerke $\mathbf{R}^{2}=0.389$

TABLE 3

Chance for meeting health recommendations for PA* considering to the level of weight

\begin{tabular}{lrlll}
\hline Variable & $\mathbf{n}$ & $\mathbf{\% a}$ & OR & CI \\
\hline BMI & & & & \\
\hline Normal & 3815 & 46.7 & Ref & \\
Overweight & 534 & 39.7 & $0.752^{* *}$ & $0.625-0.904$ \\
Obesity & 76 & 40.8 & 0.788 & $0.496-1.250$ \\
\hline
\end{tabular}

Legend: * description of the criteria for PA by WHO (2002), \% of children, who meet the criterium for PA

compared with children with normal weight. Conversely ownership of car was not significantly associated with using active transport to and from school.

Fig. 1 shows that most children aged 11, 13 and 15 consider the following to be important (or very important): "Have a safe place to cross the road." For all age categories it is also important to have an opportunity: "To leave a bicycle safely at school." On the contrary, the distance of the school from the place of residence appears unimportant, irrespective of the age of the respondents. One of significant factors influencing active transport is also the fact whether a school provides lockers where children can leave things upon arrival.

\section{DISCUSSION}

The aim of this study was to describe the level of active transport in a representative sample of Czech children and to determine the significance of some socio-demographic factors that can influence this level. The results of the analyses show that on average more than $65 \%$ of Czech school-aged children aged 11 to 15 commute to school on foot or by bicycle. In relation to socio-demographic characteristics, there are no differences between boys and girls, which corresponds with the results of a number of foreign studies such as studies by (Cooper et al., 2006), (Bringolf-Isler et al., 2008) and (Bere et al., 2008). In contrast, (Chillón et al., 2010) concluded in a study focused on Swedish (and Estonian) children that boys use active transport more often compared with girls. 
Fig. 1

Importance of factors supporting active transport to school (by age categories)

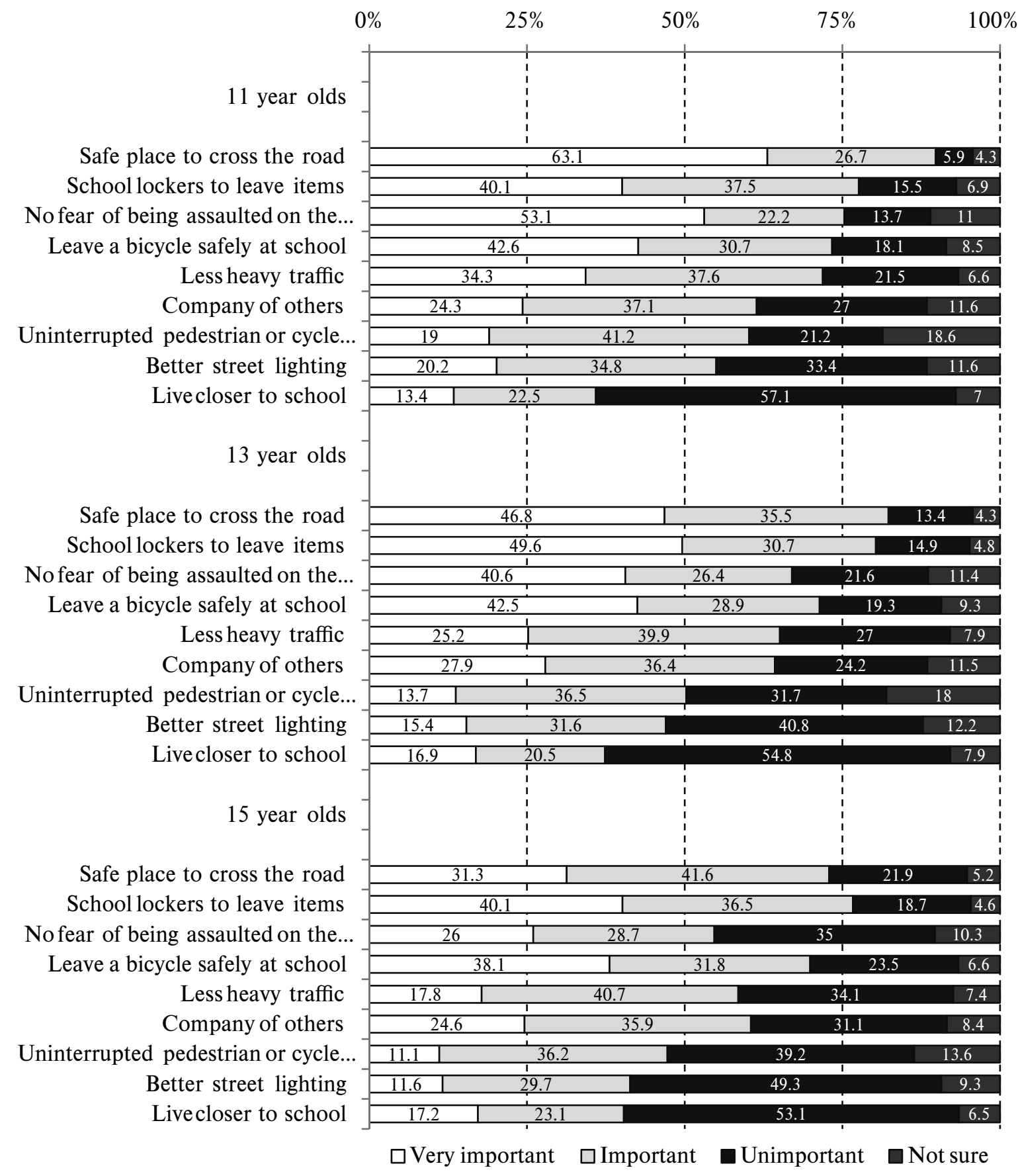

In spite of the observed higher probability of using active transport to and from school in children suffering overweight or obesity, these children have a $25 \%$ lesser chance of using physical activity recommendations. Compared with the results of foreign studies, however, no significant relations between overweight and obesity in children and their chance of using active transport were observed (Heelan et al., 2005; Landsberg et al., 2007; Rosenberg, Sallis, Conway, Cain, \& McKenzie, 2006). From this perspective, active transport, while contributing to higher levels of physical activity, though only a small part of the day and without additional leisure time PA, may not be enough to achieve PA health recommendations.

The level of active transport in school-aged children is also influenced by the location of the school and distance from the place of residence. The results of this study show that children who live in the same municipality where their school is located, have a considerably higher ( 16 times) chance of using active transport 
to school. The results of our study correspond with the work of Grize, Bringolf-Isler, Martin, and BraunFahrländer (2010), which also confirmed that students living closer to their school and in locations with lower intensity traffic use active transport more often than students living farther from their school or in locations with high intensity traffic.

One of the factors with a negative effect on active transport can be passive leisure time. In a number of foreign studies it was shown that children and young people with a high rate of sedentary behaviour tend to opt for a less active mode of transport (car, public transport) (Hamar, Biddle, Soós, Takács, \& Huszár, 2010; Pooley, Turnbull, \& Adams, 2005). Recommended amount of time spent using a computer or watching TV should not exceed two hours a day (Education, 2001; Salmon $\&$ Shilton, 2004). In a study by Carson, Kuhle, Spence, and Veugelers (2010) it was concluded that children who spend more than two hours a day using a computer have a lower probability of using active transport to and from school compared with children who spend less than two hours a day using a computer.

As far as socio-economic factors are concerned, a difference was found in the probability of using active transport between children who have or do not have their own room. International research reveals the effect of socio-economic factors on the probability of using active transport. The most commonly reported factors are the number of cars in the family, or whether the parents work full-time (Black et al., 2001; Carlin et al., 1997). Carlin et al. (1997) also state that 5 to 10 year old children in Australia in families without a car have a three times higher chance of using active transport on their way to school compared with families with one car and a seven-time higher chance compared with families with two or more cars. Regarding socio-economic factors such as ownership of a car in the family and time spent using a computer no significant influence on active transport of children was established. Having one's own room is one from four parameters of family affluence scale, which could indicated socioeconomic status of children (Currie et al., 2008; Stalsberg \& Pedersen, 2010). Our results indicated that children who have their own room are less likely to use active transport to school or from school.

The results of our study further show that, for example, a very significant factor that can support active transport in 11 year old children on their way to school includes safe places to cross the road (63.1\%). In contrast, a less important factor for the same age group is the location of their place of residence close to the school. In a number of foreign papers from various countries (USA, New Zealand, England, Canada, Australia) safety is perceived as a major obstacle to greater use of active transport by children on their way to school (Ahlport, Linnan, Vaughn, Evenson, \& Ward, 2008; Collins \& Kearns, 2001; DiGuiseppi et al., 1998; Nicholson \& O’Neill, 1999; Timperio et al., 2006).

Similarly, Yeung, Wearing, and Hills (2008) state that the most frequent factors influencing the final decision whether to use active transport on the way to school include particularly age, provision of safety of pedestrians and cycle paths, distance and the level of physical fitness.

Likewise, fast traffic is commonly referred to as a significant obstacle for pedestrians and cyclists, while easy accessibility of pedestrian and cycle paths increases the probability of active transport (Rodriguez, 2009). Some groups, especially children and the elderly, are, compared with common population, more prone to the negative health effects associated with high levels of traffic. Excessive traffic, noise, crime and bad lighting can have a negative impact on walking and cycling (Lavin, Metcalfe, \& Higgins, 2011). However, in Czech children participating in this study, the quality of street lighting is included among the least important factors influencing their use of active transport to and from school.

\section{Limitations of the study}

A strength of the HBSC study is the fact that the research uses representative data of a national sample of Czech school-aged children at an age that is very crucial for acquiring habits beneficial for an active lifestyle. Due to the international nature of the HBSC study (identical methods for all participating countries), the data is comparable with the data of the other 42 countries. The data can thus be used for international comparison and monitoring of developmental trends. A limitation of the study is that the results are based on data collected through a questionnaire survey. The conclusions of this study must be, with respect to subjective answers to the questions asked, presented with certain care.

\section{CONCLUSIONS AND RECOMMENDATIONS}

More than $80 \%$ of Czech children report usual weight according to WHO percentile graphs (de Onis \& Lobstein, 2010; de Onis et al., 2007). The probability of a higher occurrence of active transport is evident in 11 year old children but also in children with overweight and obesity. The most influential factor increasing active transport is "school in the same municipality". The most important factors that can have a positive effect on using active transport, as perceived by children, include "Have a safe place to cross the road" and have "School lockers where I can leave my things" and "No fear of being assaulted on the way". Promotion of active transport should focus on children who spend more time using a computer; attention should also be drawn to safety associated with active transport to school or from school. 


\section{ACKNOWLEDGEMENT}

This study was supported by IGA UP research project no. FTK_2011_024 (50\%), ECOP project "Strengthening the scientific potential of research teams in promoting physical activity at Palacký University” reg. no. CZ.1.07/2.3.00/20.0171 (50\%).

\section{REFERENCES}

Ahlport, K., Linnan, L., Vaughn, A., Evenson, K., $\&$ Ward, D. (2008). Barriers to and facilitators of walking and bicycling to school: Formative results from the non-motorized travel study. Health Education \& Behavior, 35(2), 221-244.

Aitken, T., Cranny, J., Ferguson, C., Graham, R., \& Middleton, B. (2009). Building healthy communities together: Active and alternative transportation to support healthy living in Grey Bruce. Retrieved 1. 11. 2012 from the World Wide Web: http://playbrucegrey.com/public_docs/documents/Active $\% 20$ $\% 20$ Alternative $\% 20$ Transportation\%20to\%20Support $\% 20$ Healthy $\% 20$ Living $\% 20$ in $\% 20$ Grey $\% 20$ Bruce.pdf

Babey, S., Hastert, T., Huang, W., \& Brown, E. (2009). Sociodemographic, family, and environmental factors associated with active commuting to school among US adolescents. Journal of Public Health Policy, 30, 203-220. doi: 10.1057/jphp.2008.61.

Bere, E., van der Horst, K., Oenema, A., Prins, R., \& Brug, J. (2008). Socio-demographic factors as correlates of active commuting to school in Rotterdam, the Netherlands. Preventive Medicine, 47(4), 412-416.

Black, C., Collins, A., \& Snell, M. (2001). Encouraging walking: The case of journey to school trips in compact urban areas. Urban Studies, 38(7), 1121-1141.

Booth, M., Okely, A., Denney-Wilson, E., Hardy, L., Dobbins, T., Wen, L., \& Rissel, C. (2007). Characteristics of travel to and from school among adolescents in NSW, Australia. Journal of paediatrics and child health, 43(11), 755-761.

Bringolf-Isler, B., Grize, L., Mäder, U., Ruch, N., Sennhauser, F., \& Braun-Fahrländer, C. (2008). Personal and environmental factors associated with active commuting to school in Switzerland. Preventive Medicine, 46(1), 67-73.

Buliung, R., Mitra, R., \& Faulkner, G. (2009). Active school transportation in the Greater Toronto area, Canada: An exploration of trends in space and time (1986-2006). Preventive Medicine, 48(6), 507-512.

Carlin, J., Stevenson, M., Roberts, I., Bennett, C., Gelman, A., \& Nolan, T. (1997). Walking to school and traffic exposure in Australian children. Australian and New Zealand Journal of Public Health, 21(3), 286-292.
Carson, V., Kuhle, S., Spence, J., \& Veugelers, P. (2010). Parents' perception of neighbourhood environment as a determinant of screen time, physical activity and active transport. Canadian Journal of Public Health, 101(2), 124-127.

Collins, D., \& Kearns, R. (2001). The safe journeys of an enterprising school: Negotiating landscapes of opportunity and risk. Health \& Place, 7(4), 293-306.

Cooper, A., Wedderkopp, N., Wang, H., Andersen, L., Froberg, K., \& Page, A. (2006). Active travel to school and cardiovascular fitness in Danish children and adolescents. Medicine \& Science in Sports \& Exercise, 38(10), 1724-1731.

Currie, C., Griebler, R., Inchley, J., Theunissen, A., Molcho, M., Samdal, O., \& Dür, W. (2010). Health Behaviour in School-aged Children (HBSC) study protocol: Background, methodology and mandatory items for the 2009/10 survey. Edinburgh: Child and Adolescent Health Research Unit (CAHRU).

Currie, C., Molcho, M., Boyce, W., Holstein, B., Torsheim, T., \& Richter, M. (2008). Researching health inequalities in adolescents: The development of the Health Behaviour in School-aged Children (HBSC) family affluence scale. Social Science \& Medicine, 66(6), 1429-1436.

Davis, A., \& Jones, L. (1996). Children in the urban environment: An issue for the new public health agenda. Health \& Place, 2(2), 107-113.

Davison, K., Werder, J., \& Lawson, C. (2008). Peer reviewed: Children's active commuting to school: Current knowledge and future directions. Preventing Chronic Diseases, 5(3), 1-11.

de Onis, M., \& Lobstein, T. (2010). Defining obesity risk status in the general childhood population: Which cut-offs should we use? International Journal of Pediatric Obesity, 5(6), 458-460. doi: $10.3109 / 17477161003615583$.

de Onis, M., Onyango, A. W., Borghi, E., Siyam, A., Nishida, C., \& Siekmann, J. (2007). Development of a WHO growth reference for school-aged children and adolescents. Bulletin of the World Health Organization, 85(9), 660-667.

DiGuiseppi, C., Roberts, I., Li, L., \& Allen, D. (1998). Determinants of car travel on daily journeys to school: Cross sectional survey of primary school children. BMJ, 316(7142), 1426-1428.

Education, C. o. P. (2001). Children, adolescents, and television. Pediatrics, 107(2), 423-426. doi: $10.1542 /$ peds.107.2.423.

Evenson, K., Huston, S., McMillen, B., Bors, P., \& Ward, D. (2003). Statewide prevalence and correlates of walking and bicycling to school. Archives of Pediatrics and Adolescent Medicine, 157(9), 887.

Farr, J. N., Blew, R. M., Lee, V. R., Lohman, T. G., \& Going, S. B. (2011). Associations of physical ac- 
tivity duration, frequency, and load with volumetric BMD, geometry, and bone strength in young girls. Osteoporos Int., 22(5), 1419-1430. doi: 10.1007/s00198-010-1361-8.

Grize, L., Bringolf-Isler, B., Martin, E., \& Braun-Fahrländer, C. (2010). Research trend in active transportation to school among Swiss school children and its associated factors: Three cross-sectional surveys 1994, 2000 and 2005. International Journal of Behavioral Nutrition and Physical Activity, 28(7), 1-8.

Hamar, P., Biddle, S., Soós, I., Takács, B., \& Huszár, A. (2010). The prevalence of sedentary behaviours and physical activity in Hungarian youth. The European Journal of Public Health, 20(1), 85-90. doi: 10.1093/eurpub/ckp100.

Healy, G., Dunstan, D., Salmon, J., Cerin, E., Shaw, J., Zimmet, P., \& Owen, N. (2008). Breaks in sedentary time. Diabetes Care, 31(4), 661-666.

Healy, G., Wijndaele, K., Dunstan, D., Shaw, J., Salmon, J., Zimmet, P., \& Owen, N. (2008). Objectively measured sedentary time, physical activity, and metabolic risk. Diabetes Care, 31(2), 369-371.

Heelan, K., Donnelly, J., Jacobsen, D., Mayo, M., Washburn, R., \& Greene, L. (2005). Active commuting to and from school and BMI in elementary school children - preliminary data. Child: Care, health and development, 31(3), 341-349.

Hillman, M., Adams, J., \& Whitelegg, J. (1990). One false move. London: Policy Studies Institute London.

Chillón, P., Ortega, F., Ruiz, J., Veidebaum, T., Oja, L., Mäestu, J., \& Sjöström, M. (2010). Active commuting to school in children and adolescents: An opportunity to increase physical activity and fitness. Scandinavian Journal of Public Health, 38(8), 873-879.

Johansson, K., Laflamme, L., \& Hasselberg, M. (2011). Active commuting to and from school among Swedish children - a national and regional study. The European Journal of Public Health, 22(2), 209-214.

Kerr, J., Rosenberg, D., Sallis, J. F., Saelens, B. E., Frank, L. D., \& Conway, T. L. (2006). Active commuting to school: Associations with environment and parental concerns. Medicine and Science in Sports and Exercise, 38(4), 787.

Landsberg, B., Plachta-Danielzik, S., Much, D., Johannsen, M., Lange, D., \& Müller, M. (2007). Associations between active commuting to school, fat mass and lifestyle factors in adolescents: The Kiel Obesity Prevention Study (KOPS). European Journal of Clinical Nutrition, 62(6), 739-747.

Lavin, T., Metcalfe, O., \& Higgins, C. (2011). Active travel - healthy lives. Dublin: The Institute of Public Health in Ireland.

Mackett, R., \& Brown, B. (2011). Transport, physical activity and health: Present knowledge and the way ahead. London: University College London.
Martin, S., Lee, S., \& Lowry, R. (2007). National prevalence and correlates of walking and bicycling to school. American Journal of Preventive Medicine, 33(2), 98-105.

McDonald, N. (2007). Active transportation to school: Trends among U.S. school children, 1969-2001. American Journal of Preventive Medicine, 32(6), 509-516. doi: 10.1016/j.amepre.2007.02.022.

Ng, S., \& Popkin, B. (2012). Time use and physical activity: A shift away from movement across the globe. Obesity Reviews, 13(8), 659-680. doi: 10.1111/j.1467789X.2011.00982.x.

Nicholson, J., \& O’Neill, J. (1999). The case for active and safe routes to school: An information and discussion paper. Ottawa: Go For Green.

Owen, N., Humpel, N., Leslie, E., Bauman, A., \& Sallis, J. (2004). Understanding environmental influences on walking: Review and research agenda. $\mathrm{Am}$. J. Prev. Med., 27(1), 67-76.

Panter, J. R., Jones, A. P., van Sluijs, E. M. F., \& Griffin, S. J. (2010). Attitudes, social support and environmental perceptions as predictors of active commuting behaviour in school children. Journal of epidemiology and community health, 64(1), 41-48.

Pooley, C., Turnbull, J., \& Adams, M. (2005). The journey to school in Britain since the 1940s: Continuity and change. Area, 37(1), 43-53.

Robertson-Wilson, J., Leatherdale, S., \& Wong, S. (2008). Social-ecological correlates of active commuting to school among high school students. Journal of Adolescent Health, 42(5), 486-495.

Rodriguez, D. (2009). Active transportation: Making the link from transportation to physical activity and obesity. San Diego: Active Living Research.

Rosenberg, D. E., Sallis, J., Conway, T., Cain, K. L., $\&$ McKenzie, T. (2006). Active transportation to school over 2 years in relation to weight status and physical activity. Obesity, 14(10), 1771-1776.

Sallis, J., Frank, L., Saelens, B., \& Kraft, M. (2004). Active transportation and physical activity: Opportunities for collaboration on transportation and public health research. Policy and Practice, 38(4), 249-268.

Salmon, J., \& Shilton, T. (2004). Endorsement of physical activity recommendations for children and youth in Australia. Journal of Science and Medicine in Sport, 7(3), 405-406. doi: 10.1016/s1440-2440(04)80036-7.

Sevick, M., Dunn, A., Morrow, M., Marcus, B., Chen, G., \& Blair, S. (2000). Cost-effectiveness of lifestyle and structured exercise interventions in sedentary adults 1: Results of project ACTIVE. American Journal of Preventive Medicine, 19(1), 1-8.

Sirard, J., \& Slater, M. (2008). Walking and bicycling to school: A review. American Journal of Lifestyle Medicine, 2(5), 372-396.

Spallek, M., Turner, C., Spinks, A., Bain, C., \& McClure, R. (2006). Walking to school: Distribution by age, 
sex and socio-economic status. Health Promotion Journal of Australia: Official Journal of Australian Association of Health Promotion Professionals, 17(2), 134.

Stalsberg, R., \& Pedersen, A. V. (2010). Effects of socioeconomic status on the physical activity in adolescents: A systematic review of the evidence. Scandinavian Journal of Medicine \& Science in Sports, 20(3), 368-383. doi: 10.1111/j.1600-0838.2009.01047.x.

Stamatakis, E., Hamer, M., \& Dunstan, D. (2011). Screen-based entertainment time, all-cause mortality, and cardiovascular eventspopulation-based study with ongoing mortality and hospital events followup. Journal of the American College of Cardiology, 57(3), 292-299. doi: 10.1016/j.jacc.2010.05.065.

Timperio, A., Ball, K., Salmon, J., Roberts, R., GilesCorti, B., Simmons, D., Baur, L. A., \& Crawford, D. (2006). Personal, family, social, and environmental correlates of active commuting to school. American Journal of Preventive Medicine, 30(1), 45-51. doi: 10.1016/j.amepre.2005.08.047.

Wahlgren, L., Stigell, E., \& Schantz, P. (2010). The active commuting route environment scale (ACRES): Development and evaluation. International Journal of Behavioral Nutrition and Physical Activity, 7(1), 1-15.

Wen, L., Orr, N., Bindon, J., \& Rissel, C. (2005). Promoting active transport in a workplace setting: Evaluation of a pilot study in Australia. Health Promotion International, 20(2), 123-133.

World Health Organization. (2002). A physically active life through everyday transport: With a special focus on children and older people and examples and approaches from Europe. Geneva: World Health Organization.

Yeung, J., Wearing, S., \& Hills, A. (2008). Child transport practices and perceived barriers in active commuting to school. Policy and Practice, 42(6), 895-900. doi: 10.1016/j.tra.2007.12.007.

\section{AKTIVNÍ TRANSPORT DĚTÍ A ŠKOLÁKŮ V ČR \\ (Souhrn anglického textu)}

VÝCHODISKA: Aktivní transport je velmi důležitým faktorem pro zvýšení úrovně pohybové aktivity dětí, která je důležitá pro jejich zdraví a pozitivní pohybové návyky v dospělém věku.

CÍLE: Cílem studie bylo popsat, kolik procent dětí ve věku 11-15 let volí v České republice aktivní způsob dopravy do školy nebo ze školy, a zároveň popsat vybrané socio-ekonomické a socio-demografické faktory, které volbu aktivního způsobu dopravy do školy nebo ze školy u dětí ovlivňují.

METODIKA: Pro zjištění socio-demografických faktorů ovlivňujících aktivní transport byla využita data národního souboru 11-15letých žáků základních škol ČR $(\mathrm{n}=4,425)$. Výzkumný sběr dat byl realizován $\mathrm{v}$ rámci mezinárodního výzkumu Health Behaviour in School Aged Children v červnu 2010. Pro statistické zpracování výsledků byla ve statistickém programu IBM SPSS v 20. použita logistická regresní analýza.

VÝSLEDKY: Aktivní způsob dopravy do školy nebo ze školy volí v České republice přibližně $2 / 3$ dětí ve věku 11-15 let. Rozdíly mezi pohlavími nejsou statisticky významné, nejvíce dětí, které volí aktivní způsob dopravy, je ve věkové skupině 11letých $(69 \%)$. Velmi důležitým faktorem, který až 16krát zvyšuje pravděpodobnost volby aktivního transportu, je místo bydliště ve stejné obci jako škola. Mezi dalši faktory, které tuto volbu ovlivňují, patří BMI, doba strávená u počítače či vlastní pokoj $v$ rodině. Pro využití aktivního transportu dětí je důležitým faktorem bezpečnost - bezpečné přecházení silnice, bezpečně nechat kolo u školy, nemít strach z přepadení během cesty či přitomnost školních skříněk, kde si děti mohou nechat věci.

ZÁVĚRY: Aktivní transport sehrává důležitou roli pro zvýšení celkové úrovně pohybové aktivity u dětí. Podpora aktivního transportu by měla být zaměřena na děti, které tráví více času u počítače, a pozornost by měla být zaměřena také na bezpečnost spojenou s realizací aktivního transportu do školy nebo ze školy.

Klícová slova: aktivní transport, chůze, jizda na kole, škola, dèti, HBSC. 


\section{Mgr. Jan Pavelka}

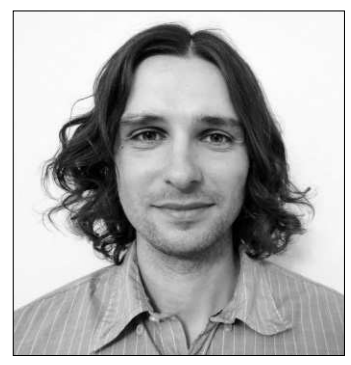

Palacký University, Olomouc Faculty of Physical Culture tř. Míru 115

77111 Olomouc

Czech Republic

Education and previous work experience 2001-2006 - Master degree in Recreology, Palacký University, Olomouc, Faculty of Physical Culture.

Since 2006 - Ph.D. student in Kinanthropology, Palacký University, Olomouc, Faculty of Physical Culture.
Work experience

Since 2006 - project manager, Department of Recreation and Leisure Studies.

Since 2010 - member of Czech national HBSC team. Since 2012 - research project worker, Institute of Active Living, Palacký University.

\section{First-line publications}

Kalman, M., Hamřík, H., \& Pavelka, J. (2012). Development of the Czech national physical activity promotion strategy: Methodological issues [Abstract]. Journal of Science and Medicine in Sport, 15 (6 Suppl.), 290.

Kalman, M., Hamřík, Z., \& Pavelka, J. (2009). Podpora pohybové aktivity pro odbornou veřejnost. Olomouc: ORE-institut. 